\title{
有機化学反応研究における ESR の応用
}

\author{
丸 山 和 博*
}

Organic Reaction as Studied by E.S.R.

Kazuhiro MARUYAMA*

\section{I. 緒言}

1945年にソビエトの物理学者 Zavoisky が，いわゆる 電子スピン共鳴吸収 (ESR または EPR) の研究を行 って以来, 急速にこの手法は改良, 進歩し, ここ数年来 の化学への応用研究には目を見はるものがある。とくに Dixon, Norman らによる流動法の開 発によって化学反 応中間に生成する短寿命の遊離基（FR と書く）の ESR による観測が可能になって以来, 有機化学反応中 間に生成するきわめて短寿命の FR の研究が数多くなさ れ，はなばなしい成果を収めつつある。ここでは有機化 学反応を中心とした ESR を用いた最近の研究について 紹介する。

ESR はまた EPR ともいわれ, 分子または原子内に 存在する不対電子に起因する常磁性を利用して, その分 子または原子の性質を測定しようとするものである。電 子は $+1 / 2,-1 / 2$ の 2 つのスヒン状態をとることがで きるが，一個の電子が同時に $+1 / 2,-1 / 2$ のスピン状 態を取ることはできない。外部から磁場が作用しないよ らな状態では電子の $+1 / 2$ のスピン状態も, $-1 / 2$ の スピン状態もエネルギー的に見れば全く同一であるが， 外部から一定方向の磁場が作用するとそのエネルギ一状 態は 2 つに分かれる。すなわち，電子のスピンに起因す る磁気モーメントの方面が，そのスピンに応じて磁場の 方向と同一方向にむいた状態と, 逆方向にむいた状態に 別かれるのである。したがって，前者の状態の方が後者 の状態よりもエネルギーが小さいわけであるが，このよ うに外部から磁場を作用することによって，2 個のエネ ルギー準位に分がれた電子のスピン状態間のエネルギー 授受を観測するのが ESR である。この 2 つのエネルギ

* 京都大学理学部 (京都市左京区北白川追分町)

* Department of Chemistry, Faculty of Science, Kyoto University, (Kitashirakawa, Oiwake-cho, Sakyo-ku, Kyoto-Shi)
一準位間のエネルギー差は外部磁場の強さに比例し, $\Delta E=\mathrm{g} \beta \mathrm{H}_{0}$ の関係によって支配される。ここで $\mathrm{H}_{0}$ は外 部磁場の強さ, $\mathrm{g}$ は分光学的分離定教 (spectroscopic splitting factor) で, 電子では約 $2.0, \beta$ はボーア磁子 で $\frac{c h}{4 \pi m c}(m:$ 電子の質量, $c$ : 光速, $h:$ プランクの定 数, $e$ は電子の電荷) という值である。 $\mathrm{g}, \beta$ は定数と見 做すことができるので $\Delta E$ は $\mathrm{H}_{0}$ に比例することになる。 この $\Delta E$ だけのエネルギーを与えるには電磁波のエネル ギーを利用すればよいので $h \nu=\mathrm{g} \beta \mathrm{H}_{0}(\nu$ ：電磁波の振動 数)の関係となる。これに数值を代入して計算しでみる と, 約 10000 ガウスの強さの外部磁場を用いた場合, 波 長約 $1 \mathrm{~cm}$ の電磁波を, 磁場約 3400 ガウスの外部磁場 を作用させた場合には約 $3 \mathrm{~cm}$ の波長の電磁波を用いれ ば共鳴吸収を観測することができることを納得し得る。 したがって ESR は原理としてはきわめて簡単であり， 磁場を発生するための磁石と, 雪磁波発振装置と, 電磁 波の吸収を察知するための鉱石検波器とがあれば, これ を増巾観測できることになる。装置と実際の観測につい ては他に成書40)があり, それを参考して頂くとしてここ では有機化学反応の研究に ESR がどのように使用され ているかということ, 抢よびその限界に注目して行きた い。図 1 に装置の大略の構成図を示す。

さて本論にはいる前に ESR を利用すればどんなこと がわかるかといらことについて簡単にふれておくことに する。ESR の研究対象となるものは不対電子をもつ物 質であればよいことはすで伐べてきたところであるが

i）その系に不対電子をもつものがあるかないかとい らことをしらべることができる。測定の限界は $10^{-8} \sim$ $10^{-9} \mathrm{~mol} / \mathrm{l}$ 位である。また既知試料と比較することによ ってその濃度が決定できる。

ii）不対電子をもつ物質の種類, さらに共鳴吸収上 の超微細構造を観測することによって，その分子内での 不対電子の分布状態, 分子の振動, 回転状態などを推察 


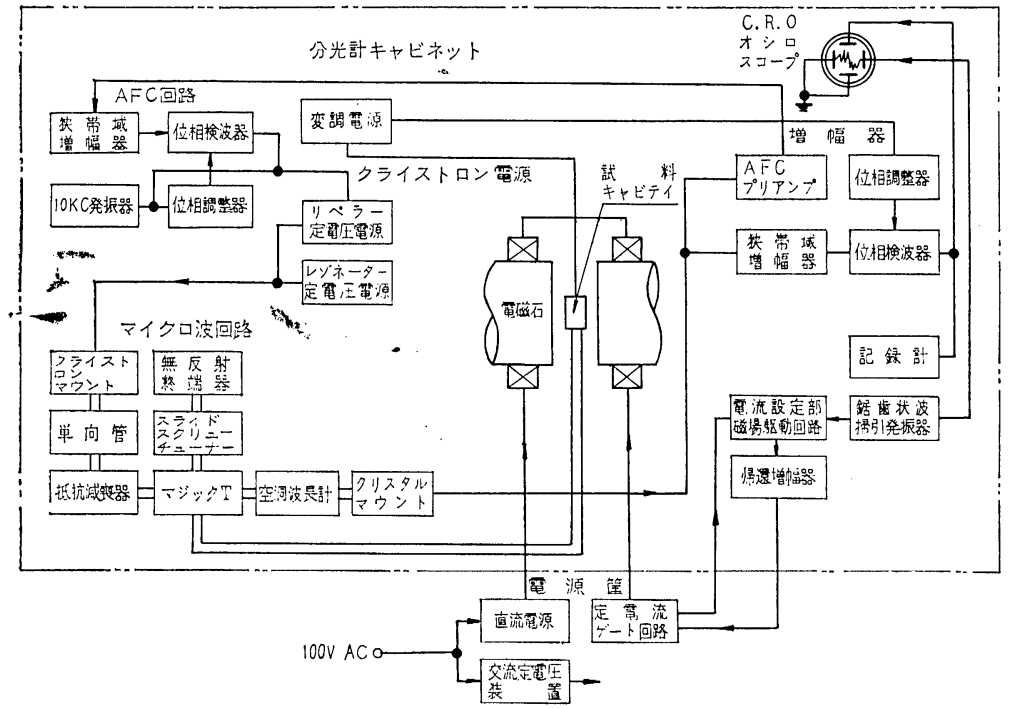

図 1 電子スピン共㗖装置の構成

できる。

iii）共鳴吸収曲線の線巾の変化を 測 定することによ ってその系に発生している不対電子の他分子との交換反 応速度を決定できる。

iv）最も特長とするところは，化学反応を行いなが ら，物理的刺激を与えながら，測定が可能であること， 不対電子のない物質が測定系に如何に大量にあっても ESR の観測には全く影響がないことなどで，トラップ 法，流動法などの手法できわめて活性な短寿命の FR も 検出することができる。

等々である。

元来 FR 機構によって進行する化学反応を, イオン機 構によって進む反応から区別するには，

1） 反応が激しくて連鎖的であること。

2）ラジカル連鎖停止剂によって反応が抑制されるこ と。

3）オレフィン類などの重合触媒となり得ること。

4）反応中間に着色生成物が生成すること。

5）反応中間体が金属面と直接反応して金屈化合物を 生成すること。

などの，どちらかというとはなはだたよりない方法で その機構を論じてきた。ところが ESR が化学の研究に用 いられるようになって，これらの不確かさは大部分取り 除かれるとになったのである。安定な FR としてよく 知られている DPPH やトリフェニルメチル，2,4,6-卜 リーt-ブチルフェノキシラジカル，およびアニオンラジ カル,カチオンラジカルなどのような FR は ESR を用い る研究では最も取り扱い易く，また最も多くの知見をわ
れわれに与えてくれる領域であ るが，これらを取り扱うことは 本稿の目的ではないのでここで は触れない。有機化学反忘にお いて二成分またはそれ以上の反 応成分を混合したときに，比較 的安定な FR を生成するような 反忘の研究は，ESR を用いて 容易に行うことができる。しか し，反応中間に一時的に生成す る短寿命の FR を観測するには 多少の工夫が必要である。つぎ に反応中間に生成する FR を ESR 法によって検索する一般 的な手法をあげる。

1. 単純混合法この方法は 反応系の温度を下げ，FR の活 性度を下げて寿命を長くして測定しようとするもので， 実験手段としては最も容易であるが，相当安定な FR を 生成するような反応にしか適用できない。

2. 流動法 反応成分をそれぞれ別の容器に入れてお き，ESR 装置の空洞 (cavity) のすぐ上か，または空洞 内で適当な流速で混合し，空洞内には常に新しい FR が 生成するようにして測定する方法で，先に述べたように 現在図 2 に示すような Dixon らの用いた手法が最もよ く使われている。すでに述べたように ESR による化学 反応の研究はこの手段によって一段と発㤅したのであ り，相当短寿命の FR もこの方法で観測することができ

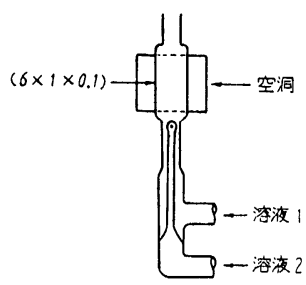

図 2 流動法セルの一例

る。事実現在化学反忘研究のほとんどすべてのものがこ の手法を用いているといっても過言ではない。

3. 凍結化法 不活性の媒質を凍結し，そのマトリッ クス内に活性な FR を捕捉して測定するものである。

以上実験方法として三つの方法に大别できるが，普通 の化学反応においてよく用いるのは (1), (2)の片法であ る。（2）の方法を用いれば，相当短寿命の FR を観測で きるとさきに述べたが，これにも限界がある。なぜなら ば普通の ESR 装置では X-バンドの電磁波を用いてお 
り，その波長は $3 \mathrm{~cm}$ である。したがってその振動数は 〜1010であるから，換言すれば流動法を用いても〜10-10 sec. よりも短寿命の FR は ESR の観測にはかからない わけであって，このような FR を観測するにはどうして も（3）の方法を用いて寿命を長くして観測する必要があ る。事実 ESR を用いる化学反応の研究にさいしての苦 労は, すべて空洞内に如何にして観測にかかる程度の濃 度の FR を作るかといら苦学である。

\section{II. 酸化反応の研究}

\section{1. フェノール類の酸化反応 有機化合物の酸化反} 応注, ESR による化学反応の研究分野として最も広く 研究されているものの一つである。そのうちでもフェノ 一ル類の酸化反応は比較的安定なフェノキシラジカルを 生成するために，よく研究されている。フェノール類が 自働酸化防止剂として作用することは一般によく知られ ているが，これはそれ自体酸化をらけ易く，FR 機構に よる連鎖反応を停止し，自らは安定な FR またはその分 解生成物に変化することによるものである。これらの関 連においてフェノール類の自働酸化経路の解明ははなは だ興味のあるものであるが，反応の進行に応じて逐次生 成してくる FR を知ることができるので ESR は有利な 方法である。Fairbourn ${ }^{1)}$ らは 2,6-ジ-t-ブチルフェノー ルのアルカリ性アルコール中での自働酸化反応を ESR を用いて追跡し，反応の進行につれて三種類の FR が生 成することをその超微細構 造の検討から明らかにし， 〔1】式の反応経路によって，これらの FR が生成し， （2）および (4) がその二つに相当し，他は反応副生物に よると考えた。

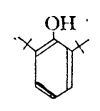

(1)
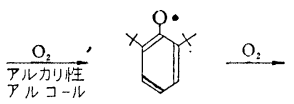

(2)

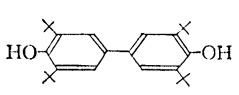

(3)

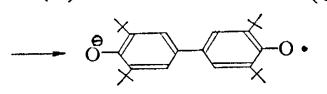

(4)
類似の反応は Bennet $^{2}$ ) によるパラアルキル置換（メチ

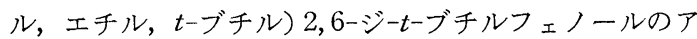
ルカリ性黄血塩による酸化反応の研究, Becconsal1 ${ }^{3)} ら$ の 2,4,6-トリアルキル置換フェノール類の過酸化 鉛に よる酸化反応の研究などに見られる。ESR 法では反応 進行に併せて生成してくるラジカル種の決定ばかりでは なく，ある種のラジカルの時間的消長をも追及すること ができるので簡単な動力学的研究も並行して行うことが できる場合がある。たとえば Bennett ${ }^{2)}$ が行ったように 生成してくるフェノキシラジカルを有機溶媒中に取り出
して酸化剂を含む水溶液相と隔離し，有機溶媒中のラジ カル濃度の減衰を観測して，これが一次反応にしたがう ことを見出し，反応は〔2】式の（b）にしたがうもので はなく，(a）にしたがい分子内水素転位機構にしたがう ものと考えている。

(a)
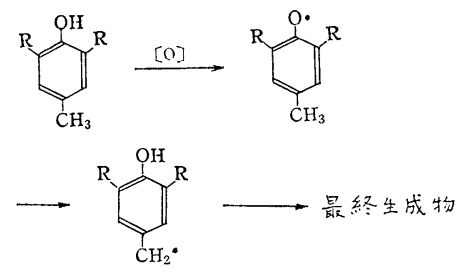

(b)
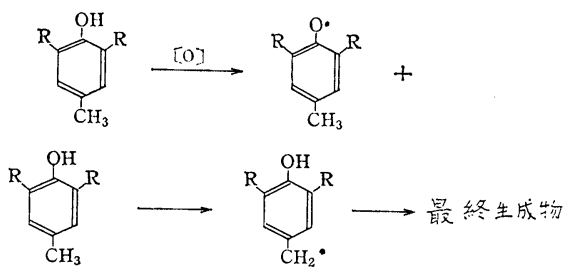

ジヒドロオキシ芳香族化合物のアルカリ性溶液中での酸 化反応も詳しく研究されつつある分野であるが，ヒドロ キノンをアルカリ性溶媒中で空気と接触させると, $p$-心 ンゾセミキノンを生成し, 1:4:6:4:1 の強度比の 5 本の超微細構造*)をもつ共鳴吸収曲線を示すことが知ら れている4)。その他多数のヒドロキノンのアルキルまた はハロゲン置換体は，同様な条件の下にセミキノンを生 成し ${ }^{5)}$,これらはすべて比較的安定な FR なので装置とし て特別の工夫をしない:簡単に ESR で研究することが できるので多数の研究が見受けられる。山崎 ${ }^{6)}$ らは酸性 〜アルカリ性水溶液中でのヒドロキノンの酸化反応途上 に生成する FRの構造を検討した。アルカリ性水溶液中 では式〔3】の（5）だけが観測されるが，低い $\mathrm{pH}$ 值で活 性を示す酸化酵素 (Horse radisch peroxidase) 老用いて 酸化し，流動法によって観測すると（6）に相当する共鳴 吸収が観測された。

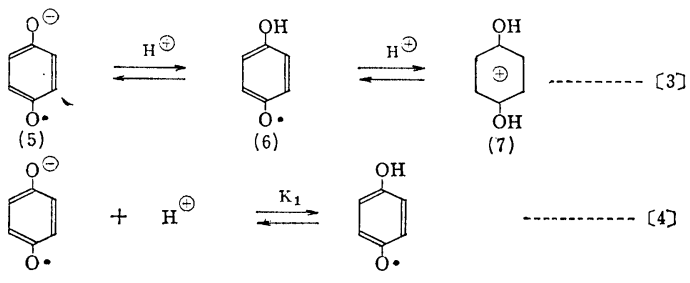

同時に $\mathrm{Ce}^{+4}$ を用いてヒドロキノンを酸化し， pH $5.2 \rightarrow$

* 超微細構造については下記の成書を参考されたい。

1) “電子スピン共鳴”（化学增刊 17), 化学同人（1964）

2）後藤，丸山，“ESR の使い方”共立出版（1965） 
$\mathrm{pH} 3.2$ に変化して行くにつれて順次共鳴吸収の型状が 変化し, 5 本の超微細構造をもつものから，3 本の超微細 構造をもつものに変化することを明らかにして,低い pH ・で (6) が生成することを証明している。また観測される 共鳴吸収線の線巾と. $\mathrm{pH}$ の值との間に直線関係が見ら れることから, 式 [4]の反応の速度定数, $k_{1}=1.5 \times$ $10^{10} / \mathrm{mol}$. sec. を算定している。

カテュール，レゾルシノールなどのアルカリ性下にお ける酸化中間体も ESR によって詳しく研究されてい $\Xi^{7)}$ 。Waters ${ }^{8)}$ らはアルカリ性エタノール中でのカテコ ールの酸化で生成する $o$-セミキノンの反応を ESR を 用いて研究し, 共鳴吸収線の経 時 変化から式〔5]に示 すような反応が進行していることを明らかにした。最近 Waters $^{9)}$ らは, さらに, 置換 カテコールのアルカリ性 下における反忘を報告した。すなわち, 溶媒に水ならび にジメチルホルムアミドを用い，単純混合法と流動法と

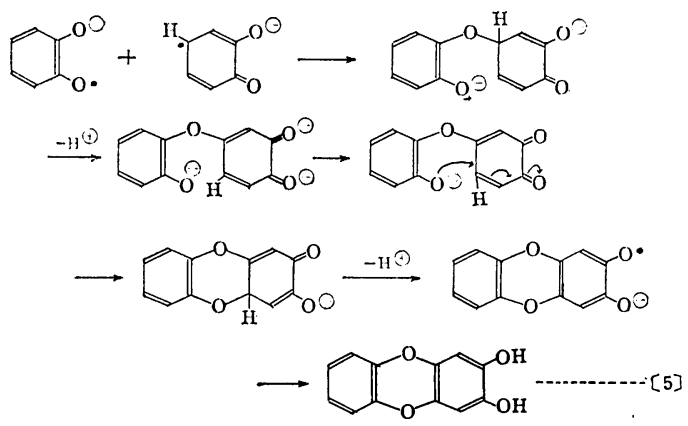

を伯用して，4-アルキル，3-アルキル，4-ホルミルなど のカテコール誘導体の酸化を行い，きわめて分解のよい 超微細構造をもつ共鳴吸収を観測して反忘中間に生成し てくる一次 FR および二次 FR の構造を決定して反応経 路を考察した。ここで興味あることは 4-アルキル置換体 と，4-カルボニル置換体とでは二次 FR の構造が異なる ことであり，一次 FRへのヒドロキシルアニオンの反応 位置の相異によることが原因であることが明らかにされ た。たとえば4-メチルカテコールの酸化経路は式〔6]に 示す反応によるものと考えられ, 他方 4-ホルミルカテコ ールの反応経路は式〔7〕に従うものと考えられるので， アルキル基とカルボニル基の配向性の差が現われるも のである。図 3 に 4-メチルカテコールの酸化によって生 成する一次 FR および二次 FR の共鳴吸収曲線(微分形) を示す。

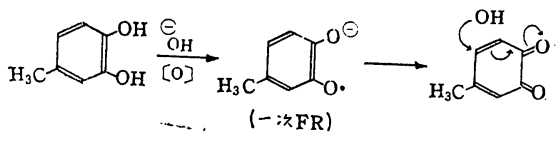

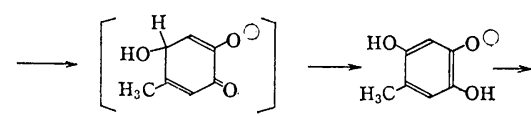
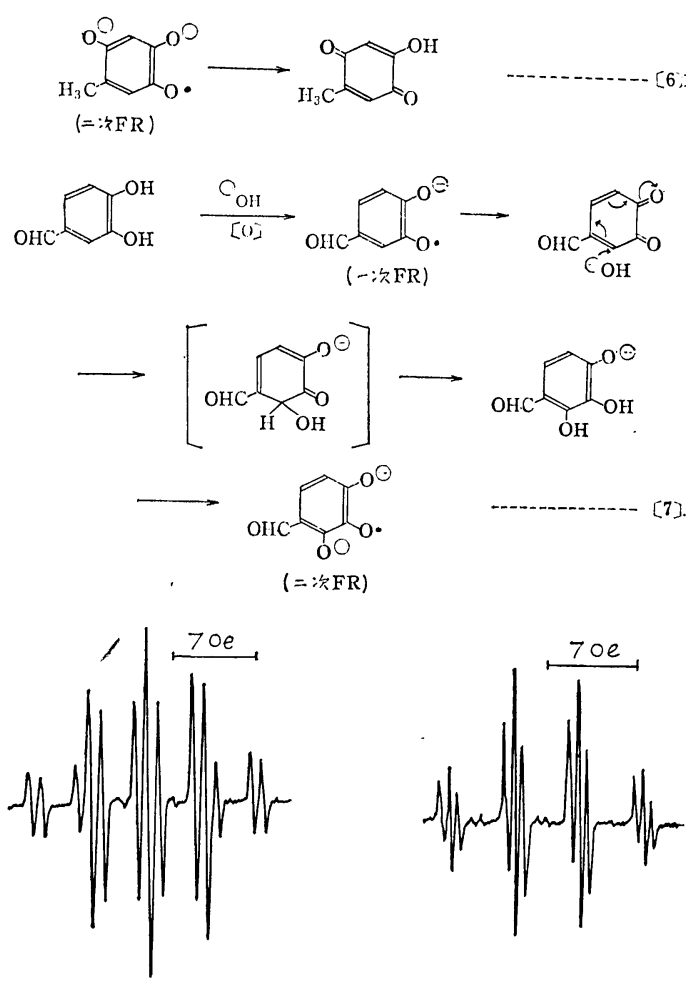

図 3 4-メチルカテュールの酸化によって生成した 一次ラジカル (a) と二次ラジカル (b)

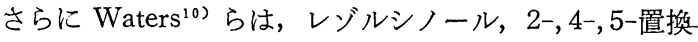
レゾルシノールのアルカリ性溶媒中ならびに酸性溶媒中 での黄血塩, 硫酸セリウムによる酸化反応を, 流動法に. よる観測によって検討し, $m$-セミキノン型のアニオンラ ジカルが生成することを明らかにしアルカリ性溶媒と酸. 性溶媒のなかとでは観測される共鳴吸収曲線の形状が異 なることから，酸性溶媒中ではレゾシノールのフェノキ シラジカルその物が得られたと考えた。なお，フェノー

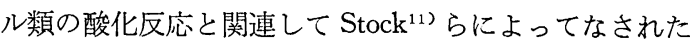
ジオキシトリプチセン〔(8) および (9)]の ESR による 研究は, 不対電子の非局在化の問題とからんで興味ある ものであるが，結果は不対電子は全く炭素橋頭に分布し ていないということが判明して，トリプチセンの 3 個の ベンゼン核間の $\pi$ 軌道の重なりが全くないことが推論で

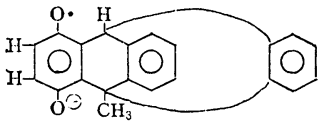

(9)

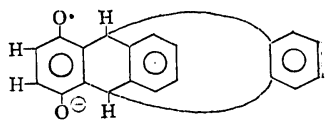

(8) 
きる。また 2,6-ジメトキシフェノール誘導体がきわめ て安定な FR (10) を生成することが ESR によって判

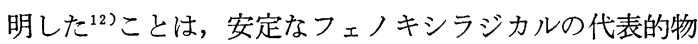
質と考えられているガルビノキシル (11) の構造と合わ せ考えると興味あるものである。

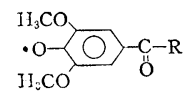

(10)

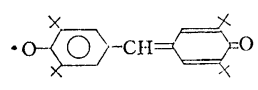

(11)
$\mathrm{R}=\mathrm{H}, \mathrm{CH}_{3}, \mathrm{C}_{2} \mathrm{H}_{5}$

2. ・OH による水素引き抜き反応 過酸化水素と $\mathrm{Fe}^{+2}$ とから得られる・OH は古くから Fenton 試薬と して用いられている酸化試剂の主役をなすものである が，・OH による水素引き抜き反応の研究は化学反応に ESR を用いた研究の中でもっとも華かな成果が得られ

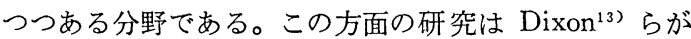
塩化第一チタン水溶液と過酸化水素水溶液とを流動法に よって混合して生成してくる・OH を ESR によって観 測したことに始まる。過酸化水素の代りに ROOH(たと えば $\mathrm{R}: \mathrm{t}-\mathrm{Bu}$ ) を用いると $\mathrm{RO} ・$ が得られるが，これも 流動法によって確認されることができた。Dixon ${ }^{14)}$ らは ベンゼン，1,3,5-トリカルボキシルベンゼン，フェノー ルトルエン等に・OH を作用させて流動法によって反応 中間に生成してくる FRの構造とその不対電子分布とを 決定した。表 1 にこれらの結果を示す。さらにベンゼン ジアゾニウム塩をチオ硫酸ソーダ水溶液で処理して, $\mathrm{Ph}-\mathrm{N}=\dot{\mathrm{N}} \longleftrightarrow \mathrm{Ph}-\dot{\mathrm{N}}-\stackrel{\ominus}{\mathrm{N}}$ に相当する FR を観測し, 強度 比 $1: 2: 3: 2: 1$ の巾広い吸収曲線を得たことから $A_{\mathrm{N}_{1}}$ $=A_{\mathrm{N} 2}=9.3$ ガウスと決定したのである。これと関連し て Fisher ${ }^{15)}$ は同様な方法を用いてフェニル酢酸，およ びベンジルアルコールの・OH による水素引抜き反応を 行い，低い酸性下（硫酸酸性 $10^{-2} \mathrm{~mol} / /$ 以下）では・OH がフェニル核に付加したと考えられるシクロヘキサジェ ニル型の FR を, 高い酸性下ではフェニル酢酸からはべ ンジルラジカルを, ベンジルアルコールからはベンジル
オキシラジカルを観測することができた（式〔8]）。
低

低酸性: $-\mathrm{CH}_{2} \mathrm{CO}_{2} \mathrm{H}+\cdot \mathrm{OH} \longrightarrow \mathrm{CH}_{\mathrm{OH}}^{\mathrm{H}}$ 型FR

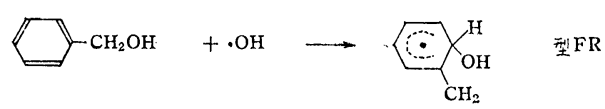

高い酸性: $\longrightarrow \mathrm{CH}_{2} \mathrm{CO}_{2} \mathrm{H}+\cdot \mathrm{OH} \longrightarrow\left[-\mathrm{CH}_{2} \mathrm{CO}_{2}{ }^{\circ}\right]$

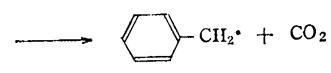

ここで，フェニル酢酸の脱カルボキシル化反応は，コル ベ電解反応，およびハンスデッカー反応と比べ合わせる と興味あるものである。実測されたベンジルラジカルの 共鳴吸収曲線を図 4 に示す。表 1 にシクロへキサジエ ニル型の FR とベンジル型の FR との分離定数を列記

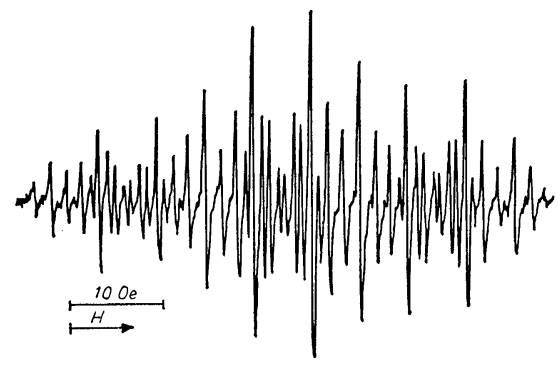

図 4 ベンジルラジカルの共鳴吸収曲線

したが，不対電子の各炭素上の分布密度は分離定数に比 例するのでこれを検討することは構造化学的に興味ある 問題を提起しているのであるが，ここでは反応だけを取 り扱うことが目的なので割愛する。ただヒドロキシベン ジルラジカルに注目してみるとフェニル基の 2-位と 6位の水素の分離定数が少しく異なっていることは注目に

表 1 ベンゼン誘導体と・OH の反応によって生成した $\mathrm{FR}^{14)}$

\begin{tabular}{|c|c|c|c|c|c|c|c|c|c|}
\hline & 化 合 物 & $0^{\mathrm{H}}$ & $\underbrace{\mathrm{HO}_{2} \mathrm{C} \mathrm{CO}_{2} \mathrm{H}}_{\mathrm{CO}_{2} \mathrm{H}}$ & & & & C.HOH & & \\
\hline \multirow{4}{*}{$\begin{array}{l}\text { 分 } \\
\text { 離 } \\
\text { 定ガ } \\
\text { 数光 }\end{array}$} & $a_{\mathrm{H}}$ (メチレン) & 36.0 & 24.4 & - & 16.4 & $16.40^{*)}$ & $15.17^{*)}$ & $50.0^{*)}$ & $47.71^{* *)}$ \\
\hline & $a_{o-\mathrm{H}}$ & 9.2 & - & 6.9 & 5.1 & 5.17 & $\begin{array}{l}4.62\left(a_{2}\right) \\
5.17\left(a_{6}\right)\end{array}$ & 10.6 & 8.99 \\
\hline & $a_{m-\mathrm{H}}$ & 2.8 & 2.7 & 1.9 & 1.6 & 1.77 & 1.63 & 2.6 & 2.65 \\
\hline & $a_{p-\mathrm{H}}$ & 13.4 & - & 10.1 & 6.3 & 5.17 & 5.88 & 10.6 & 13.04 \\
\hline
\end{tabular}

*) H. Fisher ${ }^{15,16)}$ による。

**) R.W. Fessenden ${ }^{17)}$ らによる。 
値するものである。さてベンジルアルコールの・OH に よる水素引き抜き反応でヒドロキシベンジルラジカルが 生成することを述べたが, 11種類の脂肪族アルコールに ・OH による水素引き抜きで生成する FR の研究が Dix$\mathrm{on}^{14)}$ らによって行われた。ここでも例外なく・OH の $\mathrm{H}$ 引き抜きは $\alpha$-炭素において行われることが生成してく るFR の超微細構造の解折から判明した。ただ $\alpha$-位に 水素のない- $t-\mathrm{BuOH}$ ようなものでは $\beta$-位の水素が引抜

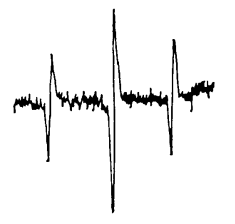

(a) メ夕ノーッ $\left(\dot{\mathrm{C}}_{2} \mathrm{OH}\right)$

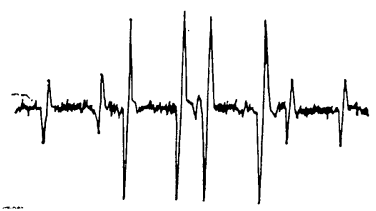

(b) エタノール $\mathrm{CH}_{3} \dot{\mathrm{CHOH}}$

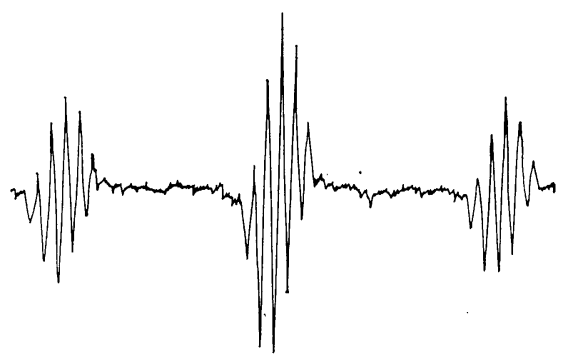

(c) tーブチルアルルール $\dot{\mathrm{C}} \mathrm{H}_{2} \mathrm{C}\left(\mathrm{CH}_{3}\right)_{2} \mathrm{OH}$

図 5 脂肪族アルコールの水菜引抜きによって生成 した FR の共鳴吸収曲線
かれる (図 5 参照)。

最近 $\mathrm{Smith}^{18)}$ らは 10 種類におよぶ低級脂肪酸および そのエステルの・OH による水素引き抜き反応を行い， 分解のよい共鳴吸収曲線を得て，これらの脂肪酸から得 られるFRの構造と各水素原子の結合定数を決定するこ とができた。表 2 に生成した FR の構造と結合定数を 示す。ここで・ $\mathrm{OH}$ の $\mathrm{C}-\mathrm{H}$ 結合攻揧の選択性は・Cl の $\mathrm{C}-\mathrm{H}$ 結合に対する選択性とほぼ一致することが明ら かにされた。Fessenden ${ }^{17)} ら も$ 同様な手法で数種の低級 脂肪酸およびそのエステルの水素抜き反応で生成してく るFR を研究したが本質的に Smith らの研究結果と同 一である。

Kolkeri9) は全く同様な方法でエーテル類の水素引き 抜き反応で生成する FR を研究して, 表 3 に示すよう な結果を得た。ここでエーテル類の自働酸化では $\alpha$-位 に酸素が攻撃してペルオキシドを生成することが知られ ているが，・OH による水素引き抜きも専ら $\alpha$-位に行わ れることが結論される。ビニルエチルエーテルの水素引 き拔き反応でアセトアルデヒドの水和物から水素原子を 引き抜いた $\mathrm{CH}_{3} \dot{\mathrm{C}}(\mathrm{OH})_{2}$ が生成しているが,これはビニ ルエチルエーテルは酸性水溶液中で加水分解してアセ卜 アルデヒドになるからだと考えられている。これに関連 して Steven ${ }^{20)} ら か ゙$ 類似条件下で行ったアルデヒド類の 水素引き抜き反応を ESR を用いて研究しているが，ア セトアルデヒドからは Kolkerの得た FR とは異なった

表 2 脂肪酸, 脂肪酸エステルの水素引き技き反态で生成した FR

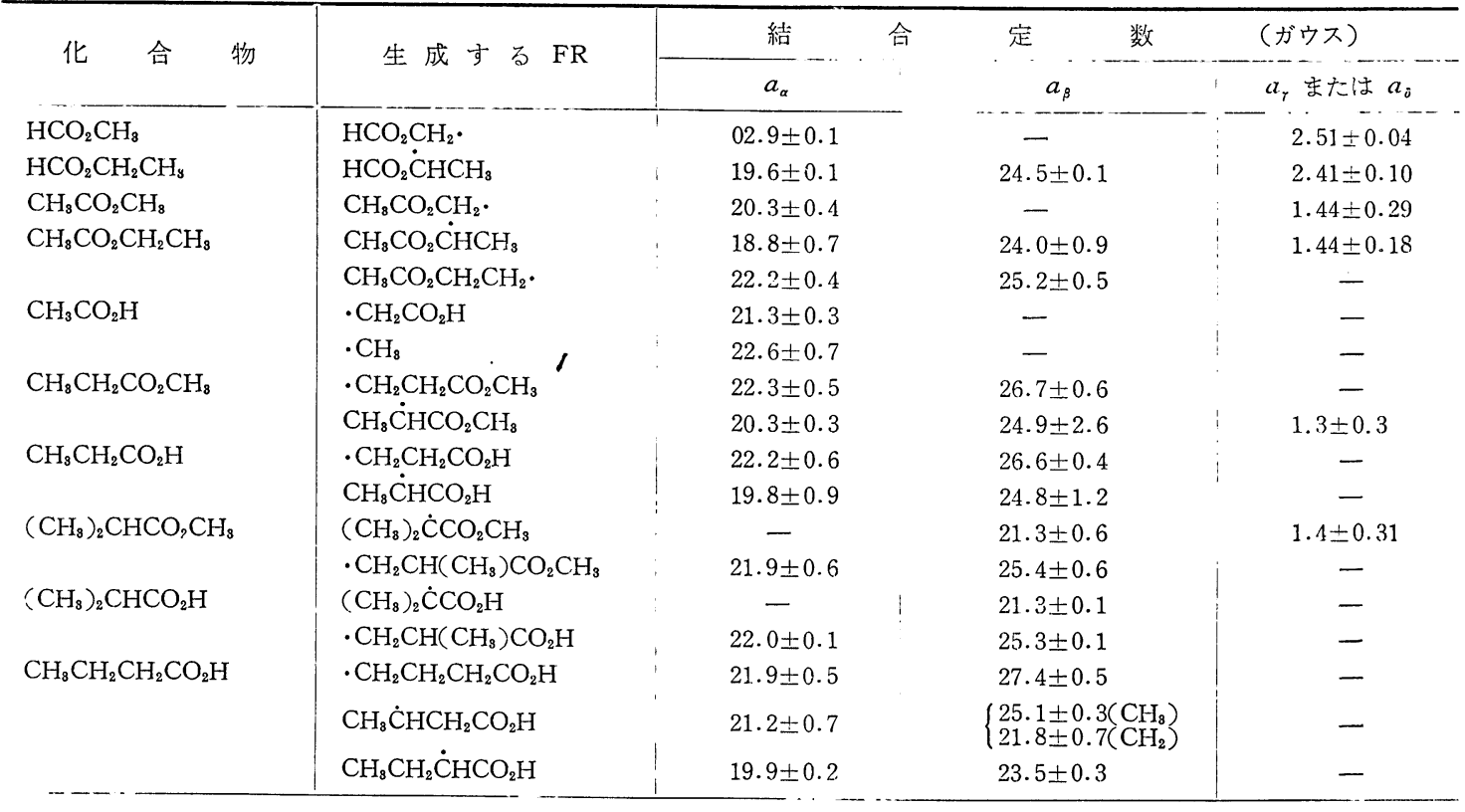


表 3 エーテル類の・OHによる水素引き抜き反応で生成した FR

\begin{tabular}{|c|c|c|c|c|}
\hline \multirow{2}{*}{$エ-テ ル$} & \multirow{2}{*}{ 生成した FR } & \multicolumn{3}{|c|}{$\begin{array}{l}\text { 結 合 定 }{ }^{\text {数 }} \\
\text { (ガウス) }\end{array}$} \\
\hline & & $a_{a}$ & $a_{\beta}$ & $a_{r}$ \\
\hline $\mathrm{CH}_{8} \mathrm{CH}_{2} \mathrm{OCH}_{2} \mathrm{CH}_{8}$ & $\mathrm{CH}_{8} \dot{\mathrm{C}} \mathrm{HOCH}_{2} \mathrm{CH}_{3}$ & 13.8 & 21.5 & 1.4 \\
\hline$\left(\mathrm{CH}_{3} \mathrm{O}\right)_{2} \mathrm{CHCH}_{3}$ & - $\mathrm{CH}_{2} \mathrm{OC}\left(\mathrm{OCH}_{3}\right) \mathrm{CH}_{2} \mathrm{CH}_{3}$ & 17.1 & - & - \\
\hline $\mathrm{CH}_{2}-\mathrm{CH}_{2}$ & & 16.6 & 45.3 & - \\
\hline $\mathrm{CH}_{3} \mathrm{OCH}_{2} \mathrm{CH}_{2} \mathrm{OH}$ & - $\mathrm{CH}_{2} \mathrm{OCH}_{2} \mathrm{CH}_{2} \mathrm{OH}$ & 16.6 & - & 2.1 \\
\hline $\mathrm{CH}_{8} \mathrm{OCH}_{2} \mathrm{CH}_{2} \mathrm{OCH}_{8}$ & - $\mathrm{CH}_{2} \mathrm{OCH}_{2} \mathrm{CH}_{2} \mathrm{OCH}_{3}$ & 16.6 & - & 2.0 \\
\hline $\mathrm{CH}_{3} \mathrm{O}\left[\mathrm{CH}_{2} \mathrm{CH}_{2} \mathrm{O}\right] \mathrm{CH}_{8}$ & - $\mathrm{CH}_{2} \mathrm{O}\left[\mathrm{CH}_{2} \mathrm{CH}_{2} \mathrm{O}\right] \mathrm{CH}_{3}$ & 16.6 & - & 2.1 \\
\hline $\mathrm{C}_{2} \mathrm{H}_{5} \mathrm{OCH}_{2} \mathrm{CH}_{2} \mathrm{CO}_{2} \mathrm{CH}_{3}$ & $\mathrm{CH}_{3} \dot{\mathrm{C}} \mathrm{HOCH}{ }_{2} \mathrm{CH}_{2} \mathrm{CO}_{2} \mathrm{CH}_{8}$ & 13.8 & 22.0 & 1.5 \\
\hline $\mathrm{CH}_{8} \mathrm{CH}_{2} \mathrm{OCH}: \mathrm{CH}_{2}$ & $\mathrm{CH}_{8} \dot{\mathrm{C}}(\mathrm{OH})_{2}$ & 14.4 & 21.6 & 一 \\
\hline $\mathrm{CH}_{3} \mathrm{COCH}_{3}$ & $\mathrm{CH}_{8} \mathrm{COCH}_{2}$. & 17.3 & - & 1.1 \\
\hline
\end{tabular}

7 本の超微細構造をもつ共鳴吸収曲線を得ている。この

FR はアセトインの水素引き抜き反応によって得られた ものと同定されるといら根拠から Steven は式〔9】のよ らな反応によって生成した FR (1) であると考えてている が，他方 Dixon ${ }^{21)} ら は$ 同一方法を用いてアセトアルデ

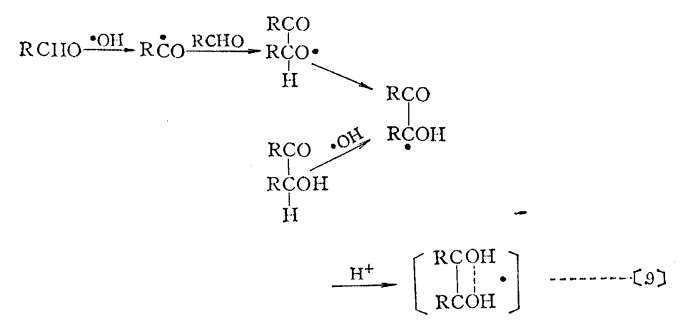

(1)

ヒドから $\mathrm{RC}(\mathrm{OH})_{2}$ 型の $\mathrm{FR}$ を得ているので, この反 経路は反応生成物の検索からも考察すべきであって, にわかには信じ難く、今後の徹底した研究が必要であろ う。これは反応機構を考察するに当って ESR から得ら れた結果だけをもって機構を考察することの危険性を示 しているように考えられる。

3. アミン類の酸化反応 第二級アミンとヒドロペ ルオキシドとの反応ではペルオキシドが還元されたアル コールとアミンの C-N 結合が切断したカルボニル化合 物と低級アミンとが生成することが知られているが, De la Mare $^{22)}$ および Coppinger ${ }^{23)}$ らは 13 種のアミン類 とヒドロペルオキシドとの反応を ESR を 用いて研究し, 反応中間に $\mathrm{R}_{1} \mathrm{R}_{2} \mathrm{NO}$ ・型の ニトロキシドラジカルが生成することを見 出し，その分解機構を考察した。また徳

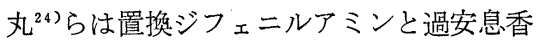
酸の反応によってジアリールニトロキシド が生成することを ESR 法を用いて研究し， ある種の置換ジフェニルアミン（たとえば $\left.p, p^{\prime}-\mathrm{di}-\mathrm{CH}_{3} \mathrm{O}-\right)$ では合成の目的に利用できるほどの収 量でニトロキシドが生成することを見出している。また 染野 $^{25)}$ らはアニリンとヒドロペルオキシドとの酸化反応 途上に FR が生成することを見出し, ESR によってその 構造を推定している。Waters ${ }^{26)} ら は p-\mathrm{R}^{\prime} \cdot \mathrm{C}_{6} \mathrm{H}_{4} \cdot \mathrm{NR}_{2}$ 型 のアニリン誘導体の硫酸セリウムによる酸化反応を 13 種 々の化合物について行い $\left(p-\mathrm{R}^{\prime} \cdot \mathrm{C}_{6} \mathrm{H}_{4} \dot{\mathrm{NR}}_{2}\right)^{+}$型のカチ才 ンラジカルが生成することを見出している。アミンとニ ンヒドリンとの反応はクロマトグラフィーにおけるアミ ン類，アミノ酸類の脿開発色法としてよく用いられるも のであるが，この発色物質は FR であるという興味ある 結果が $\mathrm{Orr}^{27}$ によって得られた。すなわちニンヒドリ ンとアミンとのメタノール溶液の温度をしだいに上昇し て行くと FR が生成したとえばジメチルアミンとニンヒ ドリンとの反応では（12）の FR が生成し，9 本の超微 細構造をもつ共鳴吸収曲線（図 6 参照）が得られた。

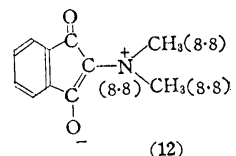

(12)

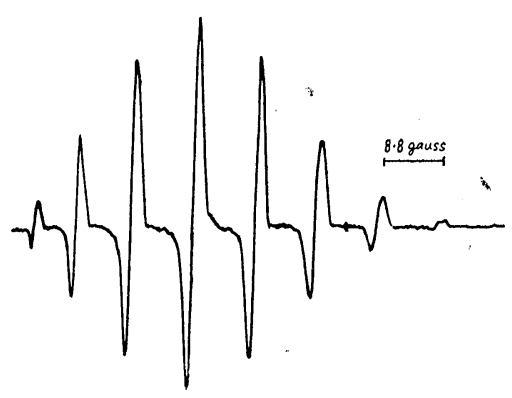

図 6 ジメチルアミンとニンヒドリンとの反応で生成 した FR の共鳴吸収曲線

丸山嘬)らはフェニル置換ヒドラジン類のヒドロペルオキ シドによる酸化反応を単純混合法によって研究し反応途 上に観測される共鳴吸収曲線の変化，反応速度 論的研 究, 反応生成物の詳細な分析結果などからその反応機構 を考察した。たとえばトリフェニルヒドラジンからは主

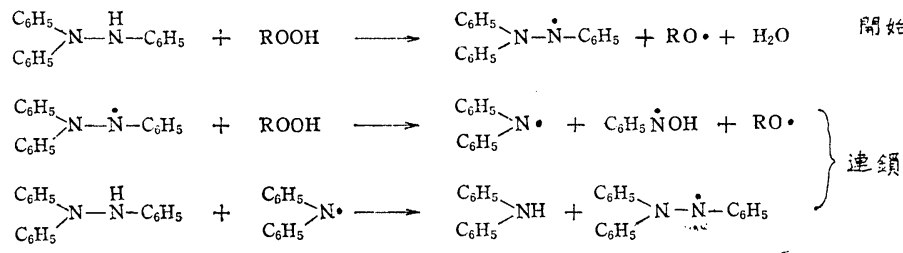

$\mathrm{C}_{6} \mathrm{H}_{5} \dot{\mathrm{NOH}}+\mathrm{RO} \longrightarrow \mathrm{C}_{6} \mathrm{H}_{5} \mathrm{NO}+\mathrm{ROH}$
停止 
としてジフェニルアミンとニトロソベンゼンとが生成す るが，この種の $\mathrm{N}-\mathrm{N}$ 結合間の開裂には反応第一段階と しての水素引き抜き反応が重要な因子となっていること から式〔10〕の反応が主反応経路であると考えている。 ヒドロキシルアミン頪の各種酸化剤による酸化反応の ESR による反応の研究は二三見受けられるが, Waters 29) らは式 [11】に示す各反忘段階を流動法を用いて研究 して FR (2), (3) の生成を見出している。

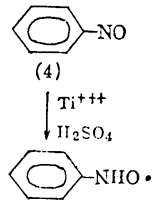

(2)

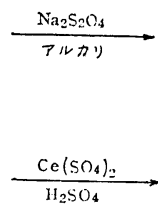

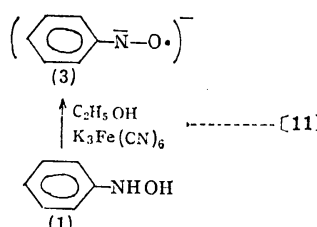

(1)

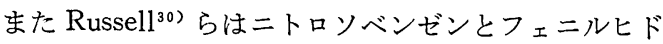
ロキシルアミンとその反応をジメチルスルホキシドの中 で行い, 塩基が反応系に存在すると $\mathrm{C}_{6} \mathrm{H}_{5} \mathrm{NO}^{\ominus}$. が生成し, 塩基がない場合には $\mathrm{C}_{6} \mathrm{H}_{5} \mathrm{NHO}$ をを経て縮合反応が起こ り，アゾキシベンゼンが生成する過程を考察した。そし て中間生成 FR の減衰は二次反応にしたがうことから $k=1.40 \times 10^{2} l / \mathrm{mol} . \mathrm{sec}$. を決定し，〔12〕式のような反 応経路を考えている。

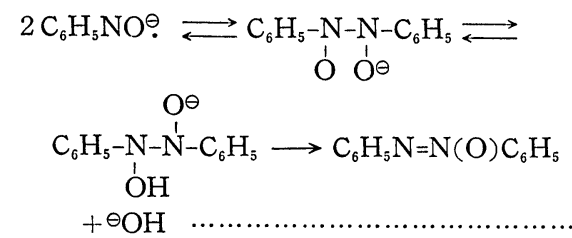

これと関連してニトロソベンゼンの光分解反応は古く Bamberger によって行われた反応であるが最近再検討 され ${ }^{31)}$, 分解生成物としてアゾキシベンゼン，2-ヒドロ キシアゾベンゼン， ジフェニルアミンなどはきわめて多 岐の物が生成することが知られている。丸山到らは置 搝ニトロソベンゼンの光分解によってニトロキシド型の FR が生成することを ESR によって見出した。したが って少くとも一部の生成物がニトロキシド FR 型を経て 分解していることは明らかであろう。

Waters $^{33)}$ らはヒドロキシルアミン，アルキルヒドロ キシルアミン，ヒドロキシカルバメートなどの硫酸セリ ウム, 黄血塩, 硝酸セリウムアンモニウムとの反応を流 動法を用いて行い RNHO・型の FR を得て，その分離 定数を決定している。興味あるのは炭酸力リウム水溶液 中でヒドロキシルアミンを酸化するとオキシカルバメー 卜型の $\mathrm{FR}, \cdot \mathrm{ONR}-\mathrm{CO}_{2} \ominus$ が生成することである。これ は式〔13〕の反応によって生成し，この FR は (13),
（14）間の共鳴によって安定化されると考えている。ま た最近極めて安定な FR であるジトリフルオルメチル $\mathrm{HONHR}+\mathrm{CO}_{3} \ominus^{2} \rightleftarrows \mathrm{HONRCO}_{2}{ }^{\ominus}+\ominus \mathrm{OH}$ $\mathrm{HONRCO}_{2} \ominus \stackrel{[\mathrm{O}]}{\longrightarrow} \cdot \mathrm{ONRCO}_{2} \ominus$

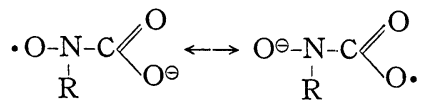

ニトロキシドが合成された。この物質は常温では紫色の ガス体であり，式〔14】の方法で合成された ${ }^{38) 。 ~}$

$\mathrm{CF}_{3} \mathrm{COOAg}+\mathrm{ClNO} \longrightarrow \mathrm{CF}_{3} \mathrm{COONO}+\mathrm{AgCl}$

$\mathrm{CF}_{3} \mathrm{COONO} \stackrel{\Delta}{\longrightarrow} \mathrm{CF}_{3} \mathrm{NO}+\mathrm{CO}_{2}$

$2 \mathrm{CF}_{3} \mathrm{NO} \stackrel{\text { 光 }}{\longrightarrow}\left(\mathrm{CF}_{3}\right)_{2} \mathrm{NONO}$

$\left(\mathrm{CF}_{3}\right)_{2} \mathrm{NONO} \underset{\mathrm{Hg}}{\stackrel{\mathrm{HCl}-\mathrm{H}_{2} \mathrm{O}}{\longrightarrow}}\left(\mathrm{CF}_{3}\right)_{2} \mathrm{NOH}$

$\underset{\text { or } \mathrm{Ag}_{2} \mathrm{O}}{\mathrm{F}_{2}}\left(\mathrm{CF}_{3}\right)_{2} \mathrm{NO}$.

オキシムも酸化剂によって安定な $\mathrm{R}_{1}>\mathrm{C}=\mathrm{N}-\mathrm{O}$ ・型の FR を生成することが Thomas $^{34)}$, Waters ${ }^{35)}$ らの流動法に よる研究で示されているが，ここでベンズアルドキシム の $\operatorname{syn}\left(a_{\mathrm{N}}=31.6\right.$ ガウス) および anti $\left(a_{\mathrm{N}}=29.2\right.$ ガ ウス）体から得られる FR の窒素原子の結合定数が異な ること， N原子の結合定数が他に比較して大きい（28〜 33 ガウス) のは, ニトロキシド型の FR がそのよらな大 きな結合定数を示さないことと比較して構造化学的に興 味あることである。このほか種々の化合物を酸化するさ いにニトロキシド型の FR を生成する例が多数知られて (る ${ }^{36)}$ 。最後に, アミン類の酸化で生成した FR の特殊 な例としてトリエチレンジアミンの酸化生成物をあげ る。トリエチレンジアミンのアセトニトリル溶液を白金 電極網で酸化すると（15）のカチオンラジカルが生成す るが，この分子中の 2 個の窒素原子は全く等価であるの みならず，12個の水素原子は全く等価であるという結論

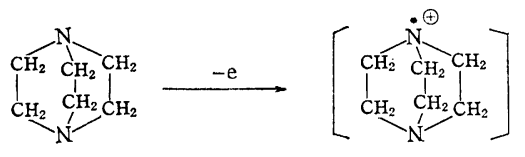

(15)

が ESR 共鳴吸収曲線の解析から得られた。これは 2 個 の窒素原子間に非常に速い電子交換があり，その線巾か らその速さは $4 \times 10^{7}$ c.p.s. 以上であると推定された。 このように原子間の不対電子交換速度を推定できるのも ESR 法の大きな特長である。

4. その他の酸化反応炭化水素, エーテル, アル デヒドなどの自働酸化途上には ROO・型のペルオキシ ラジカルが生成することは, 反応の面からよく知られて 
いたが，Thomas ${ }^{39)}$ は ABIN を開始剤とするクメンの 自働酸化途上に生成するペルオキシラジカル D-C $\left(\mathrm{CH}_{3}\right)_{2} \mathrm{OO}$ を ESR によって観測すると共に, 反応系 にピリジンを添加してその系のスピン濃度の変化を追跡 して $\mathrm{RO}_{2} \bullet+$ Pyridine $\stackrel{K}{\rightleftarrows}\left[\mathrm{RO}_{2} \ominus \cdot \cdots\right.$...Pyridine $\left.{ }^{\oplus}\right]$ の電荷 移動型錯塩生成の可能性について検討したが，Kの值は 高々 $0.4 \mathrm{l} / \mathrm{mol}$. であることを決定した。

光照射によって生成する FR の研究は，たとえば固体 アルコール中の $\mathrm{H}_{2} \mathrm{O}_{2}$ 分解による水素引き抜き反応にも 見られるように，その例は非常に多い(40)が，ここでは溶 液中の二三の反応例にのみ触れておく。p-ジメチルアミ ノベンゼンジアゾニウム塩水溶液を光分解すると, 強、 共鳴吸収を示す FR が得られたが，これは $p$-ジメチル アミノフェノールを空気酸化して得られるフェノキシラ ジカルであって二次的生成物であることが判明した ${ }^{41}$ 。 またクメン中に溶解したアゾベンゼンに光照射すると安 定な FR が得られたが，これはアゾベンゼンの窒素原子 にクミル基が付加した FR であることが明らかにされ た ${ }^{42) 。 ま た ヘ ゙ ン ソ ゙ フ ェ ノ ン を イ ソ フ ゚ ロ ヒ ゚ ル ア ル コ ー ル 中 ~}$ で光照射すると，ベンツヒドロールが好収量で生成する ことは，よく知られていることであるが，(Mauser ${ }^{43)} ら$ はこの反応を ESR で追求して, 弱いながら共鳴吸収を 示す物質が反応中間に生成したことを報告している。ま た Heller ${ }^{44)}$ はアシロインのアルコール性アルカリ水溶 液に光照射するとアニオンラジカルが生成することを ESR によって確認している（式〔15】）。

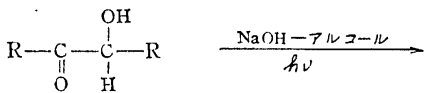

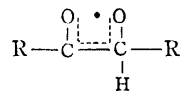$$
\mathrm{R}: \text { iso }-\mathrm{C}_{3} \mathrm{H}_{7},\left(\mathrm{CH}_{3}\right)_{3} \mathrm{C}-
$$

\section{III. 還元反応およびその他の反応}

1. 還元反応 . 芳香族炭化水素, 二トロ化合物，力 ルボニル化合物，カルボキシル化合物などの電解還元， アルカリ金属還元などによって生成するアニオンラジカ ルの ESR による研究は構造化学的にはきわめて興味深 いものであり，ESR の溶液中における研究の大部分が この方面の研究であるが，化学反応の観点からみればや や興味の薄いものである。しかしながら還元反応の素反 応を検討するという立場からいえば重要である。たとえ

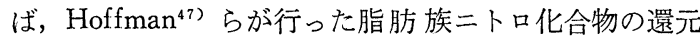
反応の研究はその好例といえよう。すなわち Hoffman らは $t$-ニトロブタン $t$-ニトロオクタン $t$-ニトロクメ
ン， 2,2'-ジニトロプロパンを電極還元ならびにアルカ リ金属還元して反応途上比成する FR を ESR で追及 するとともに(図 7 参照), 反応生成物を詳細に分析して

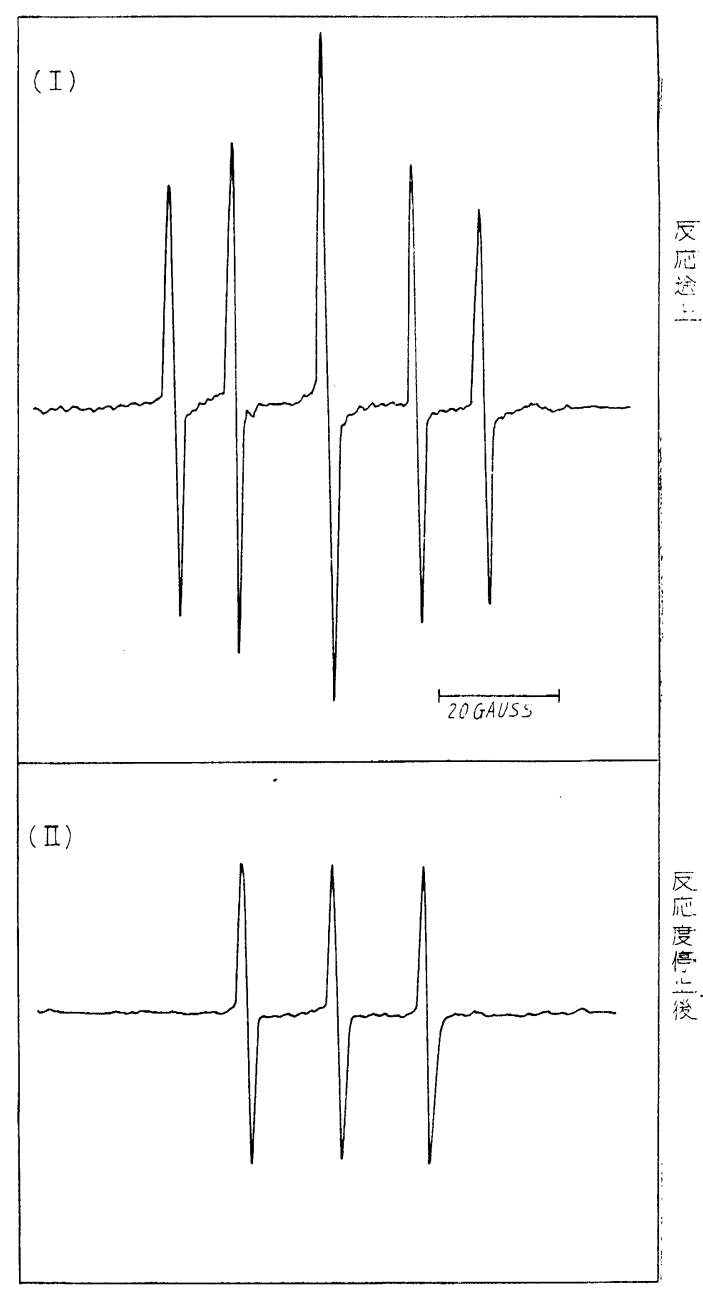

図 $7 t$-ニトロブタンの電解還元，アルカリ金属還元 で生成する FR の共鳴吸収曲線

（I）反応途上，（II）反応停止後

反応機構を考察した。図 7 からわかるように反応途上の 共鳴吸収曲線の形状 (I ) と反応停止後の曲線の形状と は明らかに異なるが，（I）をよく検討してみると（I） は（II）と他の FR の共鳴吸収とが重なり合ったもので あることがわかる。一方 $t$-ニトロブタンを金属ナトリウ ムで還元すると固体生成物が得られ，これを加水分解す ると $t$-ジブチルニトロキシドが生成することを見出し， この反応に対して式 [16]の反応機構を提出したのであ る。したがって図 7 の (II) の共鳴吸収曲線がジ- $t$-ブチ ルニトロキシドのものであり，（I）は $t$-ニトロブチル 
アニオンラジカルと（II）のそれとが重なり合ったもの である。つけ加えるとこの反応はジ- $t$-ブチルニトロキ シドの合成法としても優れ， $t$-ニトロブタンから $38.6 \%$

$$
\begin{aligned}
& t-\mathrm{C}_{4} \mathrm{H}_{9} \mathrm{NO}_{2}+\mathrm{Na} \longrightarrow t-\mathrm{C}_{4} \mathrm{H}_{9} \mathrm{NO}_{2} \ominus \mathrm{Na}^{+} \\
& \stackrel{k_{1}}{\longrightarrow} t-\mathrm{C}_{4} \mathrm{H}_{9} \cdot+\mathrm{NO}_{2}^{-}
\end{aligned}
$$

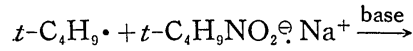

$$
\begin{aligned}
& \left(t-\mathrm{C}_{4} \mathrm{H}_{9}\right)_{2} \mathrm{NO}_{2}{ }^{-} \mathrm{Na}^{+} \\
& \left(t-\mathrm{C}_{4} \mathrm{H}_{0}\right)_{2} \mathrm{NO}_{2}{ }^{-}+\mathrm{H}_{2} \mathrm{O} \longrightarrow\left(\left(t-\mathrm{C}_{4} \mathrm{H}_{9}\right)_{2} \stackrel{+}{\mathrm{N}}\left\langle\mathrm{O}^{-}\right)\right. \\
& \longrightarrow\left(t-\mathrm{C}_{4} \mathrm{H}_{9}\right)_{2} \mathrm{NO} \cdot+\cdot \mathrm{OH}
\end{aligned}
$$

の収量で b.p. $60^{\circ} \mathrm{C} / 11 \mathrm{mmHg}$ のジ-tーブチルニトロキシ ドが生成する。アルカリ金属は電子を放出してイオン化 し易いためにアニオンラジカルを生成させる場合の還元 戍としてよく用いられるが，ESR を用いれば上述の例 々同じように，アニオンラジカルの分解過程を追及でき

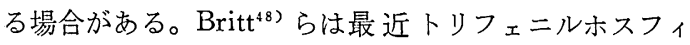
ン，フェニルビフェニレンホスフィンのアルカリ金属に よる還元を行い，トリフェニルホスフィンからはフェニ ル基が一個開裂したジフェニルホスフィンのアニオンラ ジカルを, フェニルビフェニレンホスフィンからはビフ ェニレホスフィンアニオンラジカルおよびフェニレンホ スフィンダイマーのアニオンラジカルを生成すること を ESR によって明らかにした。同じように Leffler ${ }^{49}$ らはフッ化ジメチルホウ素をナトリウムーカリウム合金 で処理してジメチルホウ素ラジカルを得，これがピリジ ンと電荷移動型錯塩を作ることを明らかにし，さらに塩 化ジフェニルホウ素は同様な処理を行らとジフェニルホ ウ素二量体のアニオンラジカルが生成し，さらにこれが ジフェニルに変化し，そのアニオンラジカルが生成する

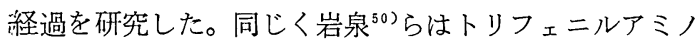
のアルカリ金属による還元分解を ESR を用いて研究し た。還元反応の特殊な例としてプロピレンと水素原子と の付加反応の研究例がある。これは空洞共振器の内部に とりつけたプロピレン薄膜に水素原子流を通じ， $\mathrm{H} ・ の$ 㝵を ESR で追跡しながら，流動法，抗散法の二つの方 法を用いて反応速度論的な研究を行った ${ }^{511}$ 。実験的に $\mathrm{H}$ ・の濃度が增加すれば 2,3-ジメチルブタンに対するプ ロパンの生成量が増加することが見出され，式〔17〕の $k_{2} / k_{3}=\sim 3.0$ (これはガス状反応のさいの值 0.5 といち じるしく異なることを研究者は強調している)， $k_{1}=1.8$ $\times 10^{6} \mathrm{cc} / \mathrm{mol}$. sec. と決定した。反応生成物は昇温後ガス クロマトグラフィーで分析している。

$$
\begin{aligned}
& \mathrm{CH}_{3}-\mathrm{CH}=\mathrm{CH}_{2}+\mathrm{H} \cdot \stackrel{k_{1}}{\longrightarrow} \mathrm{CH}_{3}-\dot{\mathrm{C}} \mathrm{H}-\mathrm{CH}_{3} \\
& 2 \mathrm{CH}_{3}-\dot{\mathrm{C}} \mathrm{H}-\mathrm{CH}_{2} \stackrel{k_{2}}{\longrightarrow} \mathrm{CH}_{3}-\mathrm{CH}_{2}-\mathrm{CH}_{3}+\mathrm{CH}_{3}-\mathrm{CH}=\mathrm{CH}_{2}
\end{aligned}
$$

$2 \mathrm{CH}_{3}-\dot{\mathrm{C}} \mathrm{H}-\mathrm{CH}_{2} \stackrel{k_{3}}{\longrightarrow} \mathrm{CH}_{3}-\mathrm{CH}\left(\mathrm{CH}_{3}\right)-\mathrm{CH}\left(\mathrm{CH}_{3}\right)-\mathrm{CH}_{3}$ $\mathrm{CH}_{3}-\dot{\mathrm{C}} \mathrm{H}-\mathrm{CH}_{3} \stackrel{k_{4}}{\longrightarrow} \mathrm{CH}_{3}-\mathrm{CH}_{2}-\mathrm{CH}_{3}$

2. その他の反応 丸山 ${ }^{522}$ はニトロソベンゼン類と グリニャール試薬との間の反応を ESR 用いて検討 し，これがラジカル機構によって進むものであることを 明らかにした。ニトロソベンゼン類 $\left(\mathrm{X}-\mathrm{C}_{6} \mathrm{H}_{4} \mathrm{NO}, \mathrm{X}\right.$ は $\mathrm{H}, \mathrm{CH}_{3}, \mathrm{Cl}$ など) とグリニャール試薬 $\left(\mathrm{C}_{6} \mathrm{H}_{5} \mathrm{MgBr}, p-\right.$ $\mathrm{CH}_{3} \mathrm{C}_{6} \mathrm{H}_{4} \mathrm{MgBr}, \mathrm{CH}_{3} \mathrm{MgI}, \mathrm{C}_{2} \mathrm{H}_{5} \mathrm{MgBr}$ など）との反応 は，ジアリールヒドロキシルアミンの合成法として古く Wieland らによる広範囲な研究があり, ニトロソベン ゼンに対してグリニャール試薬 2.5 倍量を用いたときに ヒドロキシルアミンの収量がもっともよく，また反态中 に普通のグリニャール反応では常にみられる結晶性の錯 化合物の生成がきわめて少ないか，ほとんどみられない といったような一種特別の反応である。丸山はテトラヒ ドロフラン中に溶かしたグリニャール試薬 $\left(\mathrm{C}_{6} \mathrm{H}_{5} \mathrm{MgBr}\right)$ と，ニトロソベンゼンとのおのおのをガス抜きして封じ 切った反応容器に入れ, これらをブレーク・シールによっ て接合しておき, $-80^{\circ} \mathrm{C}$ で両成分を混合反応せしめ, 前もって $-80^{\circ} \mathrm{C}$ 付近に冷却しておいた空洞共振器内に 入れ，反応の進行を ESRによって追跡した。その結果， 反応成分の混合比によって生成するラジカル濃度の違い はあるが，1:1の比に混合したときには約 70\% の割合 で $\mathrm{FR}\left(\mathrm{C}_{6} \mathrm{H}_{5} \mathrm{NC}_{6} \mathrm{H}_{5}\right)$ が生成することを見出し，さらに Ó.

ニトロソベンゼンに対してグリニャール試薬の量をしだ いに多くしたときに生成する FR の濃度が減少し, ニト ロソベンゼン：グリニャール試薬 $=1: 10$ のときにはも はや FR は観測できないことから，反応系の間につぎの 平衡があると考えた（式〔18〕）。この反応で見出される FR の共鳴吸収曲線を示す〔図 8 〕。

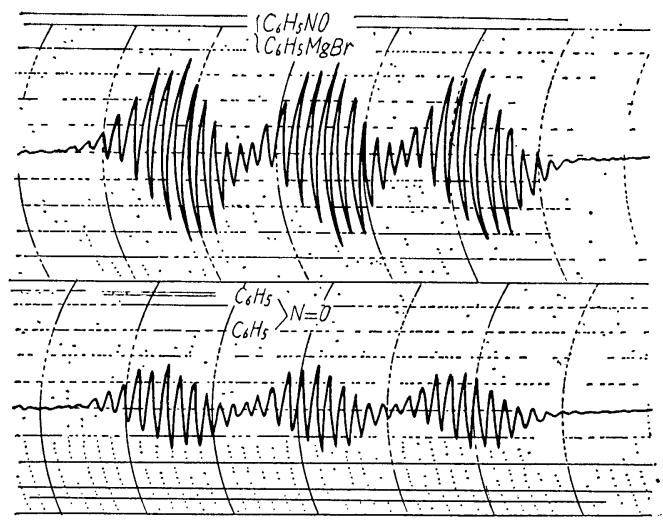

図 $8 \mathrm{C}_{6} \mathrm{H}_{5} \mathrm{MgBr}$ と $\mathrm{C}_{6} \mathrm{H}_{5} \mathrm{NO}$ との間の反応で観測さ れる FR の ESR 共鸣吸収曲線 
$\mathrm{C}_{6} \mathrm{H}_{5} \mathrm{NO}+\left(\mathrm{C}_{6} \mathrm{H}_{5} \mathrm{MgBr}\right)_{\mathrm{n}}$

$\longrightarrow \mathrm{C}_{6} \mathrm{H}_{5}-\mathrm{N}-\mathrm{C}_{6} \mathrm{H}_{5}+(\cdot \mathrm{MgBr})\left(\mathrm{C}_{6} \mathrm{H}_{5} \mathrm{MgBr}\right)_{\mathrm{n}-1}$

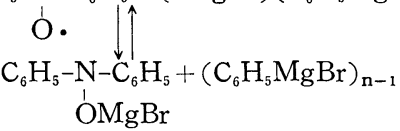

フリーデル・クラフッ反応は有機化学反応の中でも代 表的イオン反応として考えられているものであるが， Adams $^{53)}$ らはフリーデル・クラフッ反応系においても FR が観測されたことを報告している。しかしこれが如 何なる構造をもつものであるかは明らかでない。恐らく カチオンラジカルであろら。 $p$-ニトロトルエンは濃カ セイアルカリ性エタノール中で美しい桃色 (FR) 発色物 を作り，これは空気を接触することによってただちに消 え，酸素を断ってただちにふたたび着色するという経過 をたどり， pーニトロトルエンから簡単にかつ収量よく (75\%) ビベンジル誘導体を合成しうること ${ }^{54}$ はよく知 られており（式 [19]），ここに生成する桃色発色物質は FR であり，p-ニトロトルエンアニオンラジカルである ことが明らかにされた ${ }^{55)}$ 。

$$
\begin{aligned}
& \mathrm{CH}_{3}-\longrightarrow \mathrm{NO}_{2} \frac{\mathrm{KOH}-\text { エターール }}{[\mathrm{O}]} \\
& \mathrm{NO}_{2}-\square-\mathrm{CH}_{2} \mathrm{CH}_{2}-\square-\mathrm{NO}_{2}+\mathrm{H}_{2} \mathrm{O}
\end{aligned}
$$

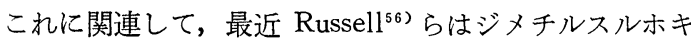
シドの塩基処理によって生成するメチルスルフィニルカ ルバニオン $\left[\mathrm{CH}_{3} \mathrm{SOCH}_{2}\right]$ が独特のメチル化㓮として 作用することを見出した。すなわち $\mathrm{NaH}, t-\mathrm{BuOK}$ など の塩基を含むジメチルスルホキシドにアントラセン，フ エナントレン, キノリン, イソキノリン, アクリジン, フェナントリジン，ニトロベンゼンなどの芳香族化合物 を作用させるとメチル化されることが判明した。メチル 化される物質は限られたものであって, 反応の機構もカ ルベンを経て進行するものではないかと考えられるが， 未だ明白でなくて，アニオンラジカルが反応に如何なる 役割を持つものか明らかではないが，式〔20]によって $\mathrm{AH}+\mathrm{CH}_{3} \mathrm{SOCH}_{2} \ominus \longrightarrow$

$\left[\mathrm{AHCH}_{2} \mathrm{SOCH}_{3}\right] \ominus$ $\longrightarrow \mathrm{ACH}_{3}+\mathrm{CH}_{3} \mathrm{SO}{ }^{\ominus}$ …......... $[20]$

表わすことができる。(DM $\mathrm{SO}-t-\mathrm{BuOK})$ 系㹥きわめ て電子を与え易い系なの でたとえばアントラセン などの反応において反応の 進行状況を, その系に生成 するアニオンラジカルを対 象に ESR で追跡すること
によって，知ることができた（図 9）。

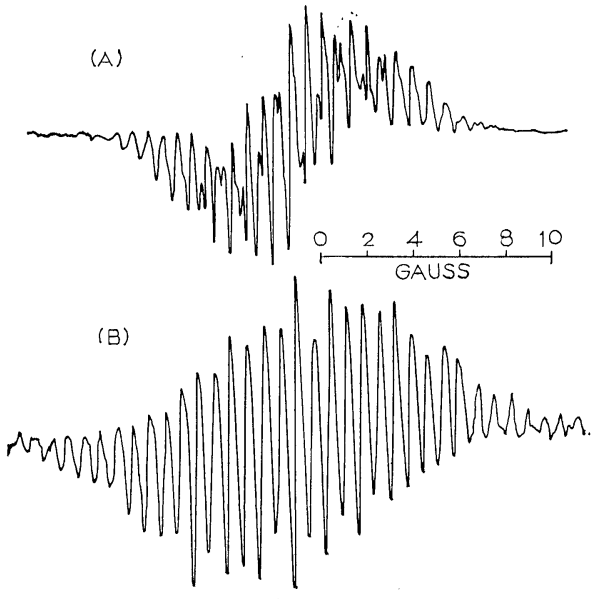

(C)

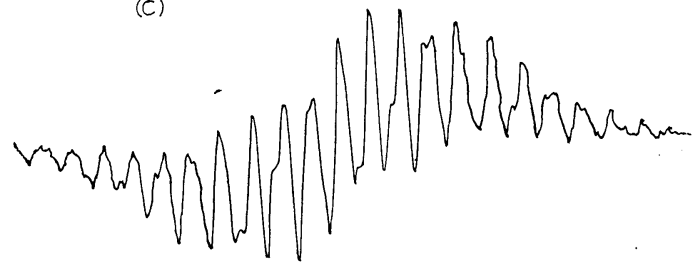

図 9 フントラセンと $\left[\mathrm{CH}_{3} \mathrm{SOCH}_{3}-t-\mathrm{BuOK}\right]$ との 反応で観測される FR. $\left(70^{\circ} \mathrm{C}\right)$

(a) アントラセン添加直後, (b) 4 時間後, (c) 9.10- シx チルアントラセンのアニオンラジカル

Fisher ${ }^{57)}$ らはアミノラジカルとオレフィン類との反 応を ESR で研究したが，最近 Dewing ${ }^{58)}$ らは $\mathrm{TiCl}_{3}$ の 硫酸水溶液とヒドロキシルアミンと混合したエチレン溶 液とを流動法で反応させてエチレンにアミノラジカルが、 付加した $\mathrm{H}_{2} \mathrm{~N}-\mathrm{CH}-\mathrm{CH}_{2}$ ・を ESR によって検出するこ とができた（図 10）。同時にエチレンを $\mathrm{H}_{2} \mathrm{O}_{2}-\mathrm{TiCl}_{3}$ 系 と反応させると $\mathrm{HO}-\mathrm{CH}_{2}-\mathrm{CH}_{2}$ ・が生成し, 共鳴 吸収曲 線は二組のトリプレット（強度比 $1: 2: 1$, 結 合 定数20.7 ガウス, 26.4 ガウス) を示すことがわかった。ま
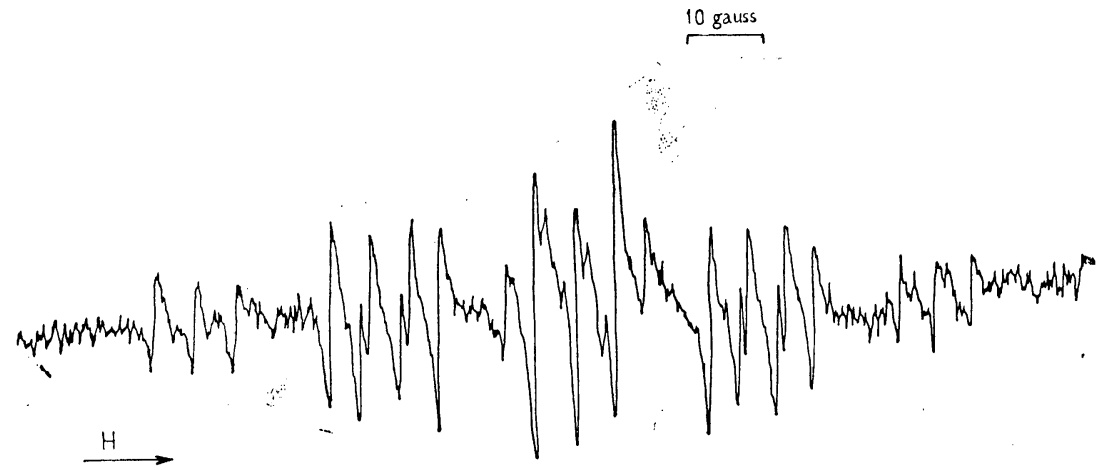

図 $10 \mathrm{H}_{2} \mathrm{~N}-\mathrm{CH}-\mathrm{CH}_{2}$ •の共鳴吸収曲線 
た Fisher ${ }^{59)}$ はメタアクリル酸およびそのエステルを水 溶液中でレドックス重合させ, その系を流動法で観測し， 重合途上に生成してくる FR を観測した。メタアクリル 酸重合途上に生成する FR については固相での研究は古 くからなされているが, 溶液中で行われた Fisher の研 究ではさらに分解のよい微細構造をもつ共鳴吸収が観測 された。

ウルツ反応の反応機構と関連して, Bennett ${ }^{60)}$ らの金 属ナトリウムとアルキルハロゲニド，アリールハロゲニ ドとの反応の ESR による研究は興味深いものである。 すなわち，低温においてナトリウムの薄膜を作り，これ にハロゲニドを蒸着し, さらにナトリウム蒸着, さらに アルキルハロゲニドの蒸着といら操作をくり返してアル キルあるいはアリール FR を生成せしめ，アルキル八ロ ゲニドのマトリックス中にトラップして観測し, 生成し た FR の構造を決定することができた。これによって式 [21]の反応が決定的となり, 温度上昇後, 生成した生

$$
\mathrm{RX}+\mathrm{Na} \longrightarrow \mathrm{R} \cdot+\mathrm{NaX} \cdot \cdots \cdot
$$

.成物はガスクロマトグラフィーで分析し, FR の二次反 応を追跡することができた。

すでに述べたように ESR の特長の一つはその系に存 在する不対電子の濃度を決定できるということである。 このことを利用して溶液中のトリフェニルメチル サフェニルエタン間に存在するような熱平衡の問題を研

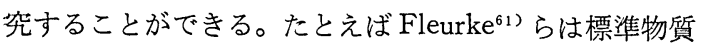
として DPPH を選び sym-テトラフェニルエタン誘導 体, ヘキサフェニルエタンの温度変化に対するその系の スピン濃度の変化を観測し, 解離エネルギー, 解離のエ ントロピーなどを決定した（表 4)。同様な研究は他に も多数あるが, 林 ${ }^{62}$ らのビイミダゾイル誘導体の研究は 熱ばかりではなく, 光, 圧力によっても解離が促進され るといわれ興味あるものといえる。熱解離の研究の一例 として Cook ${ }^{63)}$ らは sym-ビシクロへキサジェン-4-オ ン・ペルオキシド (16) の解離の研究がある。通常ペル オキシド類の熱分解では酸素-酸素間結合の切断から開 始されるのであるが，この種のペルオキシドでは酸素酸素間結合の切断ばかりではなく, 炭素-酸素間の結 合

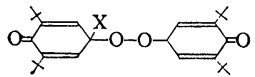

(16)

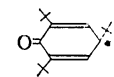

(17)

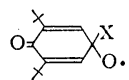

(18)
も切断するものであることが明らかにされた。すなわち （17）および（18）の生成の可能性があるわけで，炭素酸素間の結合が開裂した FR (17) 型が生成するもので はXがフェニル， $t$-ブトキシ，メトキシであって生成す る（17）の安定化と大きな関係があるといわれる。

最後に ESR の特長ある使い方として不対電子の移動 反応，および不対電子交換速度の測定などがあることを つけ加えて置きたい。前者は分子の親電子的性質老比較 するにはその系の FR の共鳴吸収曲線の超微細構造の変 化を追跡すれば，電子移動の有無を知ることができるの で, きわめてよい方法であり, 後者は中性分子とアニオ ンラジカル, ラジカルとアニオン間などの不対電子交換 のような, きわめて速い速度の反応を推定できる唯一の 方法である。

\section{IV.おわりに}

これまで有機化学反応において，とくに溶液中の反応 において，ESR がどのように利用されているかについ て, 最近の研究例を示しながら論を進めてきた。したが って, ESR の非常に重要な応用分野である分子の電子 構造の諸問題, FR と立体配座の諸問題の研究などにつ いては意識的に割愛した。化学反応の研究例でも本稿に あげたものが必ずしも代表的なものともいえず，また不 完全と思われるが, 研究分野の概略を示すことができた とすれば著者の最も幸とするところである。

(昭和 41 年 3 月 14 日受理)

\section{文献}

1) A, Fairbourn, E.A. Lucken, Proc. Chem. Soc. 196067

2) J.E. Bennett, Nature 186385 (1960)

3) J.K. Becconsall, S. Clough, G. Scott, Trans. Farad. Soc. 56459 (1960);-Proc. Chem. Soc. 1959308

4) B. Venkataraman, G.K. Fraenkel, J. Chem.

表 4 アリールエタンの熱解離

\begin{tabular}{|c|c|c|c|c|c|}
\hline 合 & $\begin{array}{l}25^{\circ} \mathrm{C} .0 .01 \mathrm{M} \text { 濃 } \\
\text { 度溶液の解離度 }\end{array}$ & $\begin{array}{c}\Delta H \\
(\mathrm{kcal} / \mathrm{mol})\end{array}$ & $\begin{array}{c}K \\
\left(25^{\circ} \mathrm{C}\right)\end{array}$ & $\begin{array}{l}d G \\
\left(25^{\circ} \mathrm{C}, \mathrm{kcal} /\right. \\
\mathrm{mol})\end{array}$ & $\begin{array}{c}\Delta S \\
\left(25^{\circ} \mathrm{C}, \text { e.u. }\right)\end{array}$ \\
\hline sym-テトラ-(2,6-ジメチルフェニル) エタン & 0.35 & 22.0 & $4.6 \times 10^{-7}$ & 8.6 & 45 \\
\hline sym-テトラ-(2-t-ジメチルフェニル) エタン & 0.61 & 19.7 & $1.5 \times 10^{-6}$ & 7.9 & 40 \\
\hline sym-テトラ-(2,6-ジメチルフェニル) エタン & 1.97 & 12.0 & $1.6 \times 10^{-5}$ & 6.6 & 18 \\
\hline ヘキサフェニルエタン & 12.00 & 10.9 & $6.6 \times 10^{-4}$ & 4.3 & 22 \\
\hline sym-テトラー(2,6-ジイソプロビルフェニル)エタン & 100 & - & - & - & - \\
\hline
\end{tabular}


Phys. 23588 (1955); J.W. Werz, J.L. Vivo, ibid. 232441 (1955) 24479 (1956) ; R.H. Hoskins, ibid 231975 (1955) 232461 (1955); J.R. Bolton et al., Proc. Chem. Soc. 1961 385; Mol. Phys. 5161 (1962); ibid. 6169 (1963)

5) B.T. Allen, W. Vanneste, Nature 204991 (19 64); T.J. Stone, W.A. Waters, J. Chem. Soc. 1964213 ; E. Müllet, K. Ley, K. Scheffer, R. Meyer, Chem. Ber. 912682 (1958)

6) I. Yamazaki, L.H. Piette, J. Am. Chem. Soc. 87986 (1965)

7) R.H. Hoskins, J. Chem. Phys. 231975 (1955)

8) F.R. Hewgill, T.J. Stone, W.A. Waters, J. Chem. Soc. 1964408

9) T.J. Stone, W.A. Waters, J. Chem. Soc. 1965 1488

10) T.J. Stone, W.A. Waters, J. Chem. Soc. 1964 4302

11) L.M. Stock, J. Suzuki, J. Am. Chem. Soc. 87 3909 (1965)

12) C. Steelink, J. Am. Chem. Soc. 872056 (1965)

13) W.T. Dixon, R.O.C. Norman, Nature 196891 (1961)

14) W.T. Dixon, R.O.C. Norman, J. Chem. Soc. 19633119 ; ibid. 19643625 ; ibid. 196367

15) H. Fisher, Z. Naturforschung. 20a 488 (1965)

16) H. Fishev, J. Chem. Phys. 371094 (1962)

17) R.W. Fessenden, R.H. Schuler, J. Chem. Phys. 392147 (1963)

18) P. Smith, J.T. Peason, P.B. Wood, T.C. Smith, J. Chem. Phys. 431535 (1965)

19) P.L. Kolker, J. Chem. Soc. 19645929

20) J.R. Steven, J.C. Ward, Chem. Comm. 1965 273

21) W.T. Dixon, R.O.C. Norman, A.L. Buley, J. Chem. Soc. 19643627

22) H.E. De la Mare, J. Org. Chem. 252114 (1960)

23) G.N. Coppinger, J.D. Swalen, J. Am. Chem. Soc. 834900 (1961)

24) 徳丸，島村，日化第 17 年会講演 (1964)

25）染野，菊地，工化 681512 (1965)

26) W.M. Fox, W.A. Waters, J. Chem. Soc. 1964 6010 ; T.J. Stone, W.A. Waters, Proc. Chem. Soc. 1962253

27) J.C. Orr, Nature 2051008 (1965)

28）丸山，大槻，昭和 40 年 8 月，日化北海道大会 講 演 日化第 19 年会講演

29) C.J.W. Gutch, W.A. Waters, Proc. Chem. Soc. 1964230

30) G.A, Russell, E.J: Geels., J. Am. Chem. Soc. 87122 (1965)

.31) H. Mauser, H. Heilzer, Z. Naturforsch. (19 65) 206203

.32) K. Maruyama, Bull. Chem. Soc. Japan 371893 (1964)

33) C.J.W. Gutch, W.A. Waters, J. Chem. Soc. 1965751

34) J.R. Thomas, J. Am. Chem. Soc. 861446
(1964)

35) W.M. Fox, W.A. Waters, J. Chem. Soc. 1965 4628

36) H.G. Aurich, F. Baer, Tetrahedron Letters 19652517 ibid. 1965 3879; W.S. Griffiths, G. R. Parlett, Nature 20469 (1964)

37) M.Mc. Kinney, D.H. Geske, J. Am. Chem. Soc. 873013 (1965)

38) W.D. Blackley, R.R. Reinhard, J. Am. Chem. Soc. 87802 (1965)

39) J. R. Thomas, J. Am. Chem. Soc. 85591 (19 63) ; ibid. 86959 (1964)

40）“電子スピン共鳴”（化学同人)増刊 17 号 (1964); D.J.E. Ingram, "Free Radicals as Studied by Electron Spin Resonance" (1958); Butterworths.

41) P.J. Zandstra, E.M. Evlcth. J. Am. Chem. Soc. 862664 (1964)

42) J.K.S. Wan, L.D. Hess, J.N. Pitts. Jr., J. Am. Chem. Soc. 862069 (1964)

43) H. Mauser, U. Sproesser, H. Heilzer, Chem. Ber. 891639 (1965)

44) H.C. Heller, J. Am. Chem. Soc. 865346 (1964)

45) P.J. Zandstra, J. Chem. Phys. 40612 (1964)

46) E.G. Janzen, C.M. Bose, Tetrahedron Letters 19652521

47) A.K. Hoffman, W.G. Hodgson, D.L. Maricle, W.H. Jura, J. Am. Chem. Soc. 86631 (1964)

48) A.D. Britt, E.T. Kaiser, J. Org. Chem. 31 112 (1966); J. Chem. Phys. 692775 (1965)

49) J.E. Leffler, E. Dolan, T. Tanigaki, J. Am. Chem. Soc. 87927 (1965)

50) M. Iwaizumi, T. Isobe, Bull. Chem. Soc. Japan 38501 (1965)

51) C.G. Hill, P.C. Reid, M.W.P. Strandberg, J. Chem. Phys. 424710 (1965)

52) K. Maruyama, Bull. Chem. Soc. Japan 371013 (1964)

53) J.Q. Adams, S.W. Nicksic, J. Am. Chem. Soc. 844355 (1962)

54) Org. Syn. Col. Vol. IV. p. 367 (1963), John. Wiley. and Sons.

55) G.A. Russell, E.G. Janzen, J. Am. Chem. Soc. 844153 (1962)

56) G.A. Russell, S.A. Weiner, J. Am. Chem. Soc. 248 (1966)

57) C. Corvaja, H. Fisher, ' G. Giacometti, $Z$. Phys. Chem. 451 (1965); H. Fisher, $Z$. Naturforsch. 19a 866 (1964)

58) J. Dewing, G.F. Longster, J. Myatt, P.F. Todd, Chem. Comm. 1965391

59) H. Fisher, Polymer Letters 2529 (1964)

60) J.E. Bennett, A. Thomas, Nature 145995 (19 62); J.E. Bennett, B. Mile, Thomas, Chem. Comm. 1965265

61) K.H. Fleuke, J. de Jong, W. Th. Nauta, Rec. Trav. Chim. 82713 (1963) 84 1059, 1386 (19 65)

62) T. Hayashi, K. Maeda, M. Takeuchi, Bull. Chem. Soc. Japan 371717 (1964)

63) C.D. Cook, M. Fraser, J. Org. Chem. 293716 (1964) 